\title{
Article \\ Electrospun Nanofiber-Based Viroblock/ZnO/PAN Hybrid Antiviral Nanocomposite for Personal Protective Applications
}

\author{
Abdul Salam ${ }^{1} \mathbb{D}^{\mathbb{D}}$, Tufail Hassan ${ }^{1}$, Tooba Jabri ${ }^{2}$, Shagufta Riaz ${ }^{3}$, Amina Khan ${ }^{4}$, Kanwal Muhammad Iqbal ${ }^{2} \mathbb{D}$, \\ Saif ullah Khan ${ }^{5}$, Muhammad Wasim ${ }^{6}$ (D), Muhammad Raza Shah ${ }^{2}$, Muhammad Qamar Khan ${ }^{1, *}$ \\ and Ick-Soo $\operatorname{Kim}^{7, *(D)}$
}

check for

updates

Citation: Salam, A.; Hassan, T.; Jabri,

T.; Riaz, S.; Khan, A.; Iqbal, K.M.;

Khan, S.u.; Wasim, M.; Shah, M.R.;

Khan, M.Q.; et al. Electrospun

Nanofiber-Based Viroblock/ZnO/

PAN Hybrid Antiviral

Nanocomposite for Personal

Protective Applications.

Nanomaterials 2021, 11, 2208.

https: / / doi.org/10.3390/

nano11092208

Academic Editor: Takuya Kitaoka

Received: 5 August 2021

Accepted: 24 August 2021

Published: 27 August 2021

Publisher's Note: MDPI stays neutral with regard to jurisdictional claims in published maps and institutional affiliations.

Copyright: (C) 2021 by the authors. Licensee MDPI, Basel, Switzerland. This article is an open access article distributed under the terms and conditions of the Creative Commons Attribution (CC BY) license (https:// creativecommons.org/licenses/by/ $4.0 /)$.
1 Nanotechnology Research Group, Department of Textile and Clothing, Faculty of Engineering and Technology, National Textile University Karachi Campus, Industrial Area Korangi, Karachi 74900, Pakistan; ab.salam@ntu.edu.pk (A.S.); hassan.tufail@ntu.edu.pk (T.H.)

2 International Center for Chemical and Biological Sciences, H.E.J. Research Institute of Chemistry, University of Karachi, Karachi 75270, Pakistan; toobaasif137@gmail.com (T.J.); kanwalmuhammadiqbal43@gmail.com (K.M.I.); raza.shah@iccs.edu (M.R.S.)

3 Functional Textile Research Group, Department of Textile Engineering, National Textile University, Faisalabad 37610, Pakistan; Shaguftariaz84@gmail.com

4 Department of Chemistry, National Textile University, Faisalabad 37610, Pakistan; aminakhan1649@gmail.com

5 Department of Textile Engineering, Balochistan University of Information Technology Engineering and Management Sciences, Quetta 87100, Pakistan; saifk1543@gmail.com

6 Key Laboratory of New Materials and Modification of Liaoning Province, School of Textile and Materials Engineering, Dalian Polytechnic University, Dalian 116034, China; Muhammad_wasim786@yahoo.com

7 Division of Frontier Fiber, Institute of Fiber Engineering, Interdisciplinary Cluster for Cutting Edge Research (ICCER), Faculty of Textile Sciences, Shinshu University, Tokida 3151, Ueda, Nagano 386 8567, Japan

* Correspondence: qamarkhan154@gmail.com (M.Q.K.); kim@shinshu-u.ac.jp (I.-S.K.); Tel.: +92-314-6300683 (M.Q.K.)

Abstract: Designing novel antiviral personal protective equipment (PPE) is crucial for preventing viral infections such as COVID-19 in humans. Here, we fabricate an electrospun nanofiber-based Viroblock (VB)-loaded polyacrylonitrile (PAN)/zinc oxide ( $\mathrm{ZnO}$ ) hybrid nanocomposite for PPE applications. Five different concentrations of Viroblock $(0.5 \%, 1.5 \%, 2.5 \%, 3.5 \%$, and $5 \%)$ were added to PAN/ZnO solution and loaded for electrospinning. The developed samples reflected antibacterial activity of $92.59 \%$ and $88.64 \%$ against Staphylococcus aureus and Pseudomonas aeruginosa bacteria, respectively, with 5\% VB loading. Moreover, a significant reduction in virus titer $(37 \%)$ was observed with the 5\% VB/PAN/ZnO nanofiber sheet. Hence, VB-loaded PAN/ZnO nanofibers have great potential to kill enveloped viruses such as influenzas and coronaviruses and could be the ideal candidate for the development of nanofiber-based PPE, such as facemasks and surgical gowns, which can play a key role in the protection of frontline health workers and the general public in the COVID-19 pandemic.

Keywords: hybrid composites; polymer fibers; face masks; polymers; nanocomposites; Viroblock; zinc oxide

\section{Introduction}

In recent times, the world has progressed in various domains, but viral infections persist to grow day by day, which not only affects human lives but also the global economy [1]. Many viral infection outbreaks have been caused by the Nipah virus [2], coronavirus [3], dengue virus [4], and influenza virus [5]. Recently a novel coronavirus (COVID-19) has caused an acute pandemic, claiming the lives of millions of people throughout the world [6]. Viruses are small infectious substances that can reproduce by attacking the host cell. Enveloped viruses (such as influenza and coronavirus), in which the capsid is enveloped by a lipid bilayer membrane, are considered to be a more dangerous form of viruses. In contrast 
to non-enveloped viruses, enveloped viruses can survive on surfaces for several days and remain infectious [7], which causes serious viral infections. There are six different stages of the pathogenesis of viral infections: (i) point of entry for virus attachment, (ii) diffusion into a host cell, (iii) virus uncoating, (iv) replication and protein synthesis, (v) assembly of the naked capsid, and (vi) release of the virion [8]. Aerosol droplets are the main source of transfer of infectious disease, and in such circumstances, personal protective equipment (PPE) such as protective gowns, face masks, and face shields can play a pivotal role in reducing the spread of viral disease [9-11]. Though most personal protective equipment can electrostatically repel or physically block the viruses and bacteria, any resident bacteria or virus that can survive on the surface of the PPE could cause contamination during disposal or reuse. Considering the current COVID-19 pandemic, due to the shortage of PPE supplies, reuse and sterilization of PPE are still challenging [12]. Fabric-based face masks are considered to be an effective shielding material against aerosol particles [13]; however, the contamination of the fabric surface can be still a big issue. To address this issue, researchers are working on surface functionalization of PPE by using different antimicrobial and antiviral agents, such as $\mathrm{ZnO}, \mathrm{TiO}_{2}, \mathrm{WO}_{3}, \mathrm{CuO}$, and $\mathrm{Ag}$ nanoparticles, to disinfect and deactivate the residing pathogens present on the surface of PPE. However, the limited affinity of the aforementioned functional nanomaterials towards textile-based PPE is a great challenge. Researchers are overcoming this challenge by using different binders or in situ growth of nanomaterials on the surface of the fabric. Seino et al. developed antiviral textile through the immobilization of silver nanoparticles on the surface of cotton fabric by using a radiochemical process [14]. Norazi et al. functionalized polyester fabric by in situ growth of $\mathrm{SiO}_{2}$ nanoparticles for antibacterial and antifungal protective clothing [15]. Shaheen et al. developed in situ zinc oxide nanoparticles on the surface of cotton fabric to enhance durability [16]. Several researchers used a binder to increase the durability of particles attached to personal protective equipment. Naka et al. reported that metal ions such as $\mathrm{Mg}, \mathrm{Ag}, \mathrm{Cu}, \mathrm{Zn}, \mathrm{Al}$, and $\mathrm{Ca}$ impart the antiviral effect to textile material [17]. Imai et al. reported that $\mathrm{Cu}$-zeolite-coated textile showed excellent antiviral activity against avian influenza virus $\mathrm{H} 5$ due to the presence of $\mathrm{Cu}^{+2}$ ions as compared to zeolite-coated textile [18]. Sumit et al. used a shellac and copper nanoparticle-based spray-assisted nanocoating on nonwoven polypropylene fabric to fabricate photoactive face masks possessing a hydrophobic surface with self-cleaning properties. Under solar light irradiation, more than $70 \%$ free radicals have been reported, which leads to the disruption of the membranes of nanosized virus-like particles [19]. Nevertheless, in the case of in situ growth of nanomaterial on PPE surfaces, particles can easily peel off during washing [20], which may cause serious health issues for the end-user, while binder functionalization diminishes comfort and sensorial properties of the personal protective clothing [21]. To fix these problems caused due to in situ growth and the use of binders, electrospinning technology is considered to be one of the best candidates for the production of durable PPE (face masks, surgical gowns, etc.), because in this case, antibacterial and antiviral materials are directly doped in the spinning solution and become part of the final produced electrospun nanofiber sheet. Moreover, the exceptional surface functionality of nanofibers corresponds with high surface area [22,23]. Cui et al. embedded $\mathrm{CuO}$ nanoparticles in hydrophobic polyvinylpyrrolidone (PVP) polymer by the electrospinning method. Oxygen plasma was used to etch the $\mathrm{CuO}$ nanoparticles in the PVP surface. Antiviral activity of the $\mathrm{CuO}$ embedded nanofibers was tested against the $\mathrm{H} 1 \mathrm{~N} 1$ virus, and results revealed that $70 \%$ of viruses were inactivated after $4 \mathrm{~h}$ of contact [24]. Rashid et al. reported that the addition of silver nanoparticles to polyaniline polymer resulted in the enhancement of both antiviral and antibacterial activity [25]. Ji et al. conducted their study on the development of side-by-side nanofibers for biomedical applications by using the electrospinning technique. One side of the prepared nanofibers was composed of $\mathrm{ZnO}$ nanoparticles, while the other side was composed of silver nanoparticles. They found that the resultant nanofibers showed excellent antibacterial activity against Gram-positive and Gram-negative bacteria [26]. In another study, Kim et al. developed an electrospun nanofiber-based membrane 
for wound dressing applications. That particular membrane was modified by using silver nanoparticles assisted by polydopamine (PDA). The resultant silver nanoparticle functionalized membranes were biocompatible and had antibacterial activity against Gram-positive and Gram-negative bacteria [27]. Chowdhury et al. developed a bio-based antiviral mask by using the electrospinning technique and claimed that licorice root extract loaded into Polyvinyl alcohol (PVA) electrospun nanofibers had the potential of killing the bacteria and viruses due to the presence of glycyrrhetinic acid and glycyrrhizin [28]. Multifunctional poly(methyl methacrylate) (PMMA) nanofibers decorated with $\mathrm{ZnO}$ nanorods and silver nanoparticles provide significant protection against Gram-positive and Gram-negative bacteria as well as protect against viruses like coronavirus and influenza viruses [29].

Herein, considering the current COVID-19 pandemic situation and excessive demand for protective clothing, we are the first to present a robust methodology to develop efficient antiviral and antibacterial electrospun nanofibrous membranes by incorporating HeiQ Viroblock (VB) and $\mathrm{ZnO}$ nanoparticles in a polyacrylonitrile (PAN) electrospun solution. Zinc oxide is a multifunctional material with exceptional properties (photocatalysis, antibacterial properties, ultraviolet (UV) protector) [30,31], but in this specific study, it acted as an antibacterial agent. HeiQ Viroblock is a white viscous liquid that encompasses two main components, namely a vesicle component and a silver component [32]. The vesicle component contains cosmetic grade liposome, which is responsible for the direct depletion of the envelope of the viruses, while the silver component contains nanoscale silver particles that have the potential to destroy the bacteria and viruses [33-35]. The developed electrospun nanofibers have the potential to be used for protective clothing (surgical gowns, face masks) against enveloped viruses (influenza, coronaviruses) and bacteria (Gram-negative and Gram-positive).

\section{Materials and Methods}

\subsection{Materials}

All the chemicals were purchased from different sources and used in this study without further additional purification. Polyacrylonitrile (PAN, MW $=150,000 \mathrm{~g} / \mathrm{mol}$ ) was used as the main precursor material for the fabrication of nanofibers due to its better fouling properties, high chemical stability, and high mechanical strength [36]. Polyacrylonitrile was purchased from Sigma Aldrich, Seoul, Korea. Zinc oxide nanoparticles (ZnO NPs, 50-60 nm), acting as an antibacterial and UV protective agent, were procured from Sigma Aldrich, Seoul, Korea. Viroblock (combination of silver and lipid vesicle), acting as an antiviral as well as an antibacterial agent, was purchased from HEIQ Concord, NC, USA. N,N-Dimethylformamide (DMF, MW $=73.1 \mathrm{~g} / \mathrm{mol}, 99.5 \%$, Reagent Grade), used as a solvent, was purchased from DaeJung, Seoul, Korea.

\subsection{Preparation of Pristine PAN, PAN/ZnO, and VB-Loaded PAN/ZnO Electrospinning Solutions}

In this study, a total of seven different solutions were prepared. Pure PAN solution $(10 \mathrm{wt} \%)$ was prepared by dissolving $1 \mathrm{~g}$ of PAN powder in $9 \mathrm{~g}$ of $\mathrm{N}, \mathrm{N}$-dimethylformamide (DMF) solvent. The solution was allowed to stir magnetically on the magnetic stirrer for about $10 \mathrm{~h}$ at a stirring speed of $500 \mathrm{rpm}$ to form a homogeneous solution. For the $\mathrm{PAN} / \mathrm{ZnO}$ composite solution, $5 \mathrm{wt} \% \mathrm{ZnO}$ nanoparticles were added and allowed to stir magnetically at $500 \mathrm{rpm}$ for approximately $15 \mathrm{~h}$. Moreover, different solutions of PAN/ZnO loaded with VB (different concentrations, namely $0.5 \mathrm{wt} \%, 1.5 \mathrm{wt} \%, 2.5 \mathrm{wt} \%, 3.5 \mathrm{wt} \%$, and $5 \mathrm{wt} \%$ ) were prepared by allowing the composite solution to stir magnetically at $500 \mathrm{rpm}$ for approximately $23 \mathrm{~h}$. In all the prepared VB-loaded $\mathrm{ZnO} / \mathrm{PAN}$ composite solutions, the concentration of $\mathrm{ZnO}$ nanoparticles remained constant.

\subsection{Fabrication of Electrospun Nanofibers}

For the fabrication of pure PAN electrospun nanofibers, PAN solution was poured in $10 \mathrm{~mL}$ of a disposable syringe, which was connected to the pipette tip. A copper wire acting as a positive electrode was fitted inside the syringe. The solution in the form of nanofibers 
was drawn through the tip of the syringe under the applied voltage of $17 \mathrm{kV}$. These extruded fibers were collected on the aluminum foil wrapped on the negative charged rotating cylinder (collector). The distance between the collector and tip of the syringe was kept at $15 \mathrm{~cm}$ while maintaining the flow rate of $1 \mathrm{~mL} / \mathrm{h}$. Similarly, this process was repeated for the fabrication of PAN/ZnO and VB-loaded PAN/ZnO electrospun nanofibers. The illustration scheme and possible reaction of fabrication of electrospun nanofibers are shown in Figures 1 and 2, respectively.

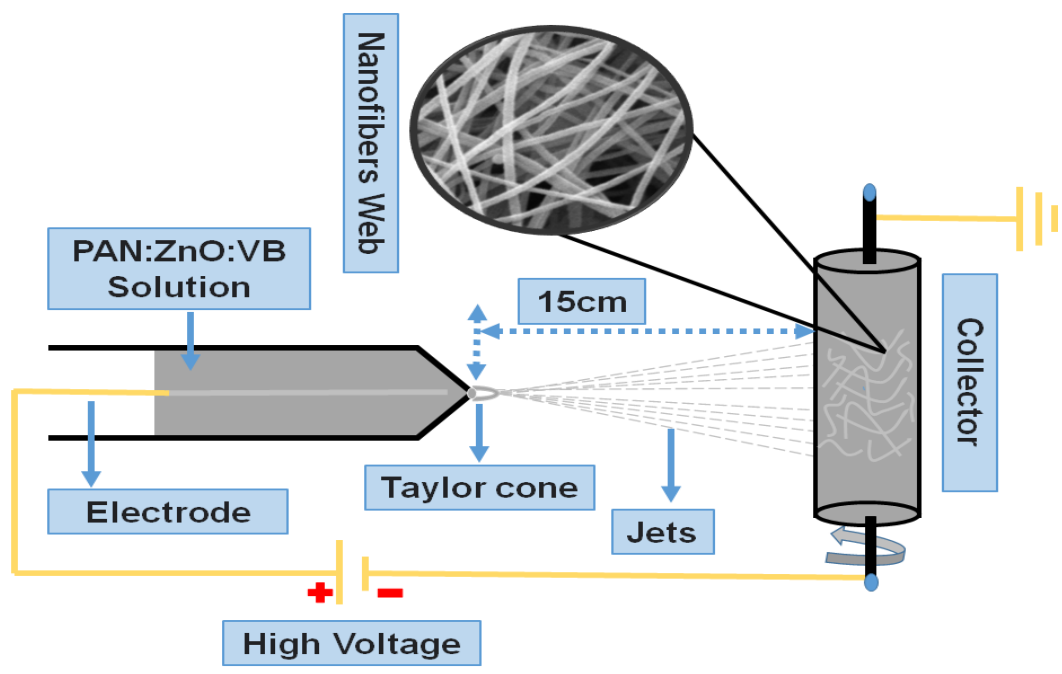

Figure 1. Illustration scheme of fabrication of antiviral nanofibers.

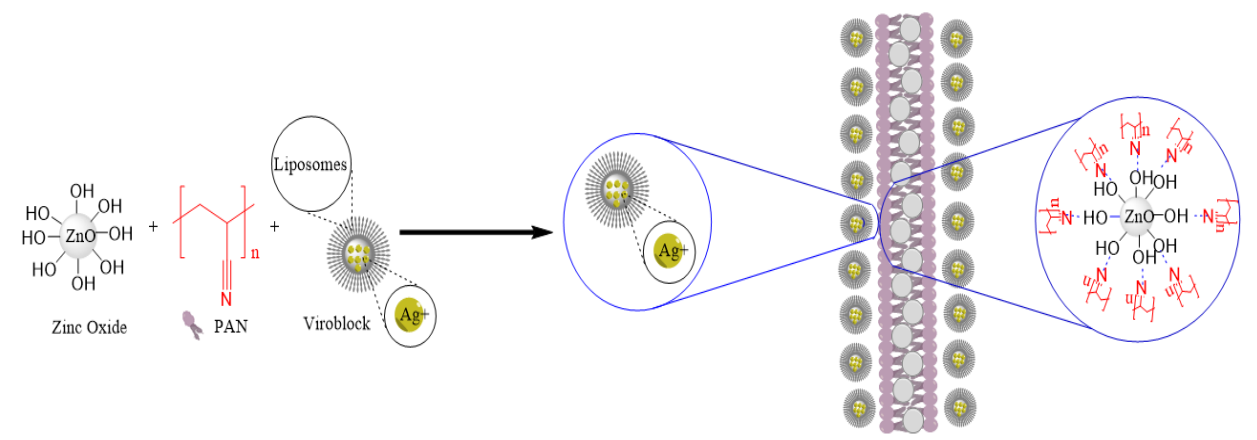

Figure 2. Chemical reaction for the fabrication of antiviral nanofibers.

\section{Characterization}

\subsection{Surface Morphology}

The surface morphology of the prepared electrospun nanofibers was analyzed by using a scanning electron microscope (SEM) (Model: JSM-5300, Tokyo, Japan), by applying $12 \mathrm{kV}$ voltage. ImageJ software (version 1.49) was used to calculate the average diameter of electrospun nanofibers by taking 200 random measurements from each prepared sample [22].

\subsection{Transmission Electron Microscope (TEM) Analysis}

To check the uniform distribution of nanoparticles and VB in electrospun nanofibers, TEM analysis was used. High-resolution TEM (JEOL ARM 200F, Tokyo, Japan) was used to capture the TEM images at a working voltage of $200 \mathrm{kV}[37,38]$.

\subsection{Chemical Interaction (FTIR)}

The chemical interaction between PAN, ZnO NPs, and Viroblock (VB) was analyzed by Fourier Transform Infrared (FTIR) (PerkinElmer, Billerica, MA, USA). Spectra of all the 
prepared samples were recorded from $400 \mathrm{~cm}^{-1}$ to $4000 \mathrm{~cm}^{-1}$. The spectra were recorded with 128 scans with a resolution of $4 \mathrm{~cm}^{-1}$.

\subsection{Antibacterial Activity Protocol}

Quantitative antibacterial analysis of prepared electrospun nanofibers was conducted by following the AATCC-100 standard [39]. According to this standard, the samples were shaken in the bacterial suspension of known concentration, and a reduction in the bacterial activity was noted in standard time. Antibacterial activity was characterized by measuring the viable microbial cells present on the nanofibers. To determine the change of Pseudomonas aeruginosa and Staphylococcus aureus contact with nanofibers, the bacterial plate method was applied for various time points.

The bacterial culture broth was incubated overnight. The triplicate method [40] was used to analyze the antibacterial activity of the electrospun nanofibers, while the average value was reported. Samples of nanofibers were cut into small circular pieces and submerged in the ethanol $(75 \%)$ and dried before inoculation. Bacterial culture was diluted with cold $0.9 \%(v / v)$ silane solution $\left(2 \times 10^{5} \mathrm{CFU} / \mathrm{mL}\right)$. Moreover, the bacterial inoculum was cooled down to slow down the bacterial growth. The nanofibers were inoculated with $200 \mu \mathrm{L}$ of cold and diluted bacteria and afterward placed in $20 \mathrm{~mL}$ of cold silane solution and shaken for a minute to detach the bacteria. The treated mixture was serially diluted in a 1:10 ratio and spread on a media agar plate for incubation at $37^{\circ} \mathrm{C}$ for $24 \mathrm{~h}$. The rate of inhibition or antibacterial efficiency was calculated by using the following formula:

$$
\mathrm{R}=\frac{A-B}{A} \times 100
$$

here,

$\mathrm{R}=$ antibacterial efficiency (reduction percentage);

$A=$ no. of bacteria in the broth detached from the membrane after inoculation at $0 \mathrm{~h}$;

$B=$ no. of bacteria recovered from the broth after $24 \mathrm{~h}$ of contact with a treated membrane.

\subsection{Assessment of Antiviral Activity}

The antiviral activity was evaluated by the following procedure. Firstly, a sample suspension of disinfectant was mixed with an infectious dose (ELD50) of avian influenza (AI) virus with an equal volume 1:1 ( $1 \mathrm{~mL}$ disinfectant $+1 \mathrm{~mL}$ virus infectious dose) and vortexed for $5 \mathrm{~s}$ followed by incubation for $2 \mathrm{~h}$ at $2-8{ }^{\circ} \mathrm{C}$ in a shaking incubator. After that, $100 \mu \mathrm{L}$ of each mixture was inoculated via the chorioallantoic sac route with 8 embryonated eggs of each group. The hole-in-eggs were then sealed with molten wax and incubated for $48-72 \mathrm{~h}$ and were daily monitored to examine the viability of embryos. After inoculation, eggs were chilled to $24 \mathrm{~h}$ to settle down the Red Blood Cells (RBCs), eggshells were removed from the top of the eggs, and $10 \mathrm{~mL}$ allantoic fluid (AF) was harvested and centrifuged at $5000 \mathrm{rpm}$ for $5 \mathrm{~min}$ for the removal of debris from AF. Supernatant was collected to check the virus growth. To check the virus titers, $50 \mu \mathrm{L}$ of saline in a U-shaped bottom 96 -well microtiter plate was used; $50 \mu \mathrm{L}$ of tested AF was added in the first column of the 96-well plate, and subsequent wells were added typically with two folds up to the eleventh column. The final well served as a negative control with no virus. After serial dilution, $0.7-1 \%$ of chick RBCs were added to each well and mixed gently. The plates were incubated for $30 \mathrm{~min}$ at room temperature. Following the incubation period, the assay was analyzed by agglutination reaction and button formation [41].

\section{Results and Discussion}

\subsection{Surface Morphology of Electrospun Nanofibers}

Figure 3 shows the surface morphology and average diameter of prepared electrospun nanofibers. Figure $3 a$ represents the pristine PAN electrospun nanofibers having a length that ranges from hundreds of micrometers to millimeters. It can be observed that the 
surface of pristine PAN nanofiber is smoother and well-oriented compared to the other samples. By the incorporation of $\mathrm{ZnO}$ nanoparticles, the surface of nanofibers became courser and rougher. This roughness may be due to the agglomeration properties of $\mathrm{ZnO}$ nanoparticles on the surface of PAN electrospun nanofibers, as shown in Figure $3 \mathrm{~b}-\mathrm{g}$. The diameter of prepared electrospun nanofibers was calculated by using Image J software. Two hundred measurements for each prepared sample were taken from different areas, and the average diameter was calculated by plotting histograms. As seen in Figure 3a, a minimum average diameter of $127 \pm 24.8 \mathrm{~nm}$ was observed in the case of pristine PAN electrospun nanofibers. The maximum average diameter of $171 \pm 29.88 \mathrm{~nm}$ was observed in the case of $5 \%$ loaded $\mathrm{ZnO} / \mathrm{PAN}$ electrospun nanofibers, as shown in Figure 3g. In the case of Figure 3b-g, the observed average diameters were 136, 138, 140, 152, and $154 \mathrm{~nm}$, respectively. It could be observed that as the concentration of VB increased, the average diameter of the electrospun nanofibers continued to increase. This could be explained by the fact that by incorporation of $\mathrm{ZnO}$ nanoparticles and $\mathrm{VB}$ in the polymer solution, the viscosity of the solution continued to increase, which may have resulted in a steadier and courser diameter of electrospun nanofibers [42,43].
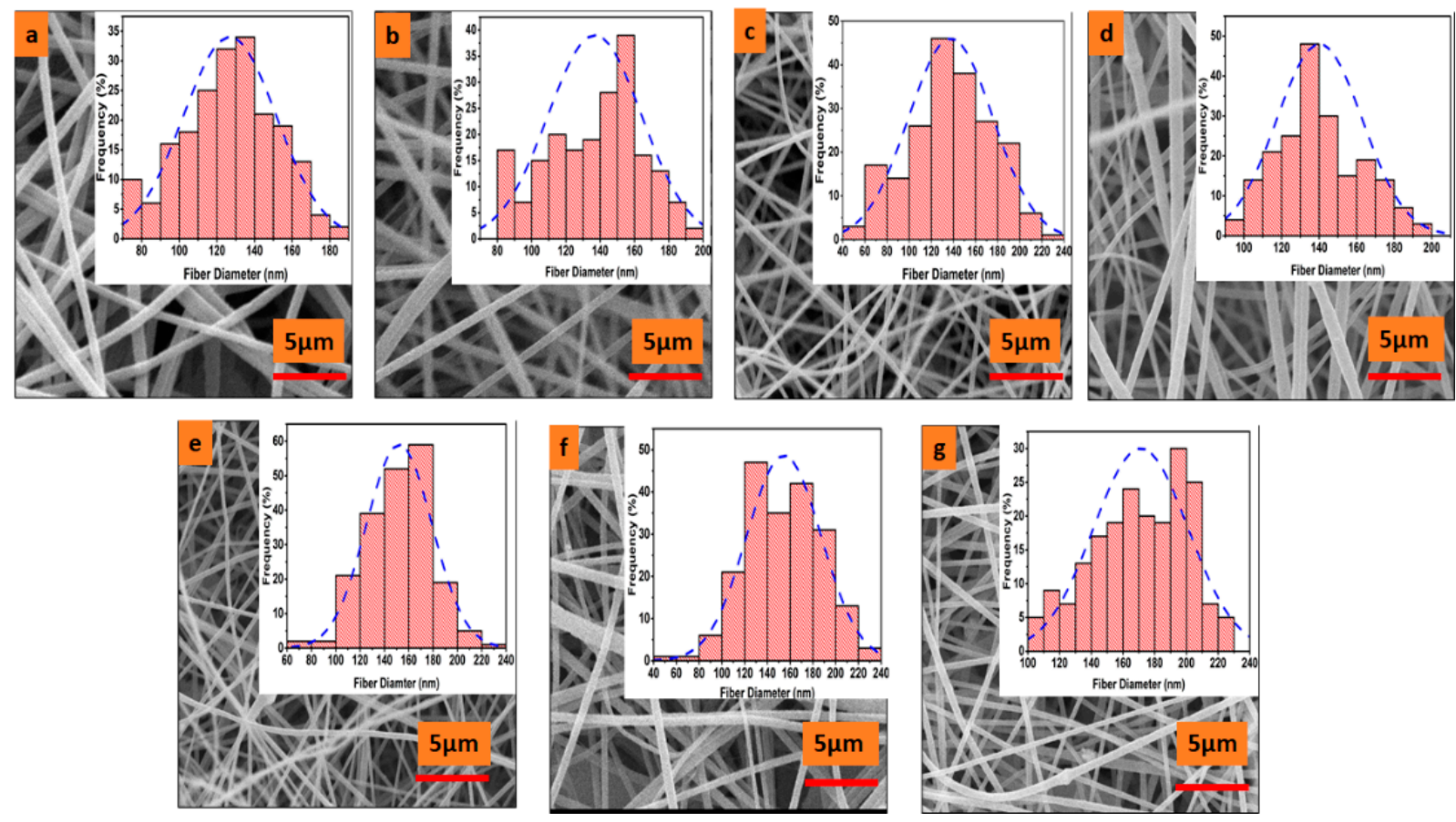

Figure 3. Surface morphology and average diameter of prepared VB-loaded ZnO/PAN electrospun nanofibers, (a) pristine PAN electrospun nanofibers, (b) ZnO/PAN electrospun nanofibers, (c) $0.5 \%$ VB-loaded ZnO/PAN electrospun nanofibers, (d) 1.5\% VB-loaded ZnO/PAN electrospun nanofibers, (e) 2.5\% VB-loaded ZnO/PAN electrospun nanofibers, (f) $3.5 \%$ VB-loaded ZnO/PAN electrospun nanofibers, (g) 5\% VB-loaded ZnO/PAN electrospun nanofibers.

\subsection{TEM Analysis of Electrospun Nanofibers}

To investigate the effect of ZnO NPs and VB on the morphology of pristine PAN, $\mathrm{PAN} / \mathrm{ZnO}$, and PAN/ZnO/VB nanofibers, TEM images were studied, as shown in Figure 4. It was confirmed that neat PAN nanofibers had a smooth surface, but the surface morphology of PAN/VB/ZnO nanofibers became rough and blackish spots appeared on the surface by the doping of $\mathrm{VB}$ in the spinning solution. It was also confirmed that there were $\mathrm{NPs}$ of $\mathrm{ZnO}$ at the surface of the PAN/ZnO/VB nanofibers. Figure $4 \mathrm{~g}$ reveals that due to the maximum concentration (5\%) of $\mathrm{VB}$ in the PAN/ZnO/VB nanofibers, the blackish shade was increased as compared to the low concentrations. 

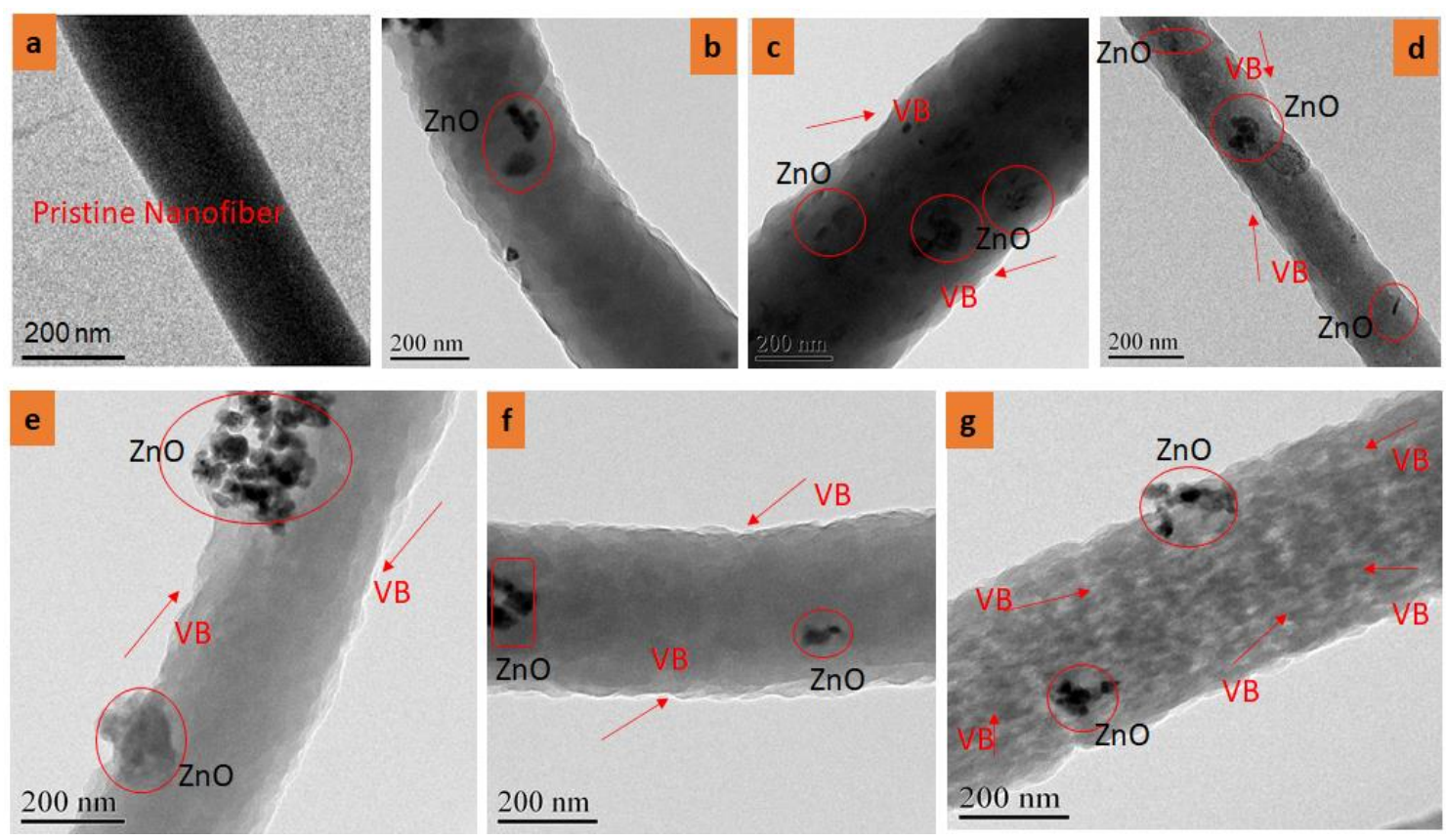

Figure 4. TEM analysis of Prepared VB-loaded ZnO/PAN electrospun nanofibers: (a) pristine PAN electrospun nanofibers; (b) ZnO/PAN electrospun nanofibers; (c) 0.5\% VB-loaded ZnO/PAN electrospun nanofibers; (d) 1.5\% VB-loaded ZnO/PAN electrospun nanofibers; (e) 2.5\% VB-loaded ZnO/PAN electrospun nanofibers; (f) $3.5 \%$ VB-loaded ZnO/PAN electrospun nanofibers; (g) 5\% VB-loaded ZnO/PAN electrospun nanofibers.

\subsection{FTIR Analysis of Electrospun Nanofibers}

To understand the structure of prepared electrospun nanofibers, FTIR analysis was performed, as shown in Figure 5. In all spectra $(\mathrm{a}-\mathrm{g})$ there was broadband that appeared at wavenumbers of $3400 \mathrm{~cm}^{-1}$ to $3500 \mathrm{~cm}^{-1}$ corresponding to the $-\mathrm{OH}$ functional group. This band increased largely as $\mathrm{ZnO}$ and $\mathrm{VB}$ were added to the electrospun nanofibers. The $-\mathrm{OH}$ band had more depth in the case of spectrum B than spectrum $\mathrm{A}$, which might be due to the hydrophilic nature of $\mathrm{ZnO}$, which allowed more - $\mathrm{OH}$ radical to be absorbed onto electrospun nanofibers. However, by increasing the concentration of Viroblock, this band further increased, and the broadness of the band decreased, which might have been due to the presence of highly reactive silver ions $\left(\mathrm{Ag}^{+}\right)$in the VB that could attract more hydroxyl radicals from the atmosphere, as shown in $(\mathrm{b}-\mathrm{g})$. In all spectra, the characteristic peaks appeared at $2918.7,2852.43$, and $1453.26 \mathrm{~cm}^{-1}$, which corresponded to $-\mathrm{CH}$ group vibration and stretching due to alkene. The sharp peaks appeared at 1731.5 and $2242.61 \mathrm{~cm}^{-1}$ indicating $\mathrm{C}=\mathrm{O}$ stretching and $-\mathrm{C} \equiv \mathrm{N}$ stretching due to acrylamide [44]. The characteristics peaks in all spectra appearing at $1042.77,1177.91,1357.21$, and $1597.29 \mathrm{~cm}^{-1}$ were related to $\mathrm{C}-\mathrm{H}$ stretching, $\mathrm{C}=\mathrm{O}$ stretching, $-\mathrm{OH}$ bending, and $\mathrm{N}-\mathrm{H}$ bending, respectively. In all spectra (except a and b), a minute peak appeared at $2991.37 \mathrm{~cm}^{-1}$ corresponding to the $-\mathrm{OH}$ group, which might be due to the presence of silver ions $\left(\mathrm{Ag}^{+}\right)$, as well as polar liposomes present in the Viroblock. These silver ions and liposomes tend to attract moisture from the atmosphere. In Figure $5 B-G$, the characteristic peak at $858.61 \mathrm{~cm}^{-1}$ was due to the vibrational bond of $\mathrm{ZnO}$; however, this peak did not appear in the case of pristine PAN electrospun nanofibers [45]. We are confident that all the attractions between the PAN, Viroblock, and $\mathrm{ZnO}$ were physical, not chemical [46]. 


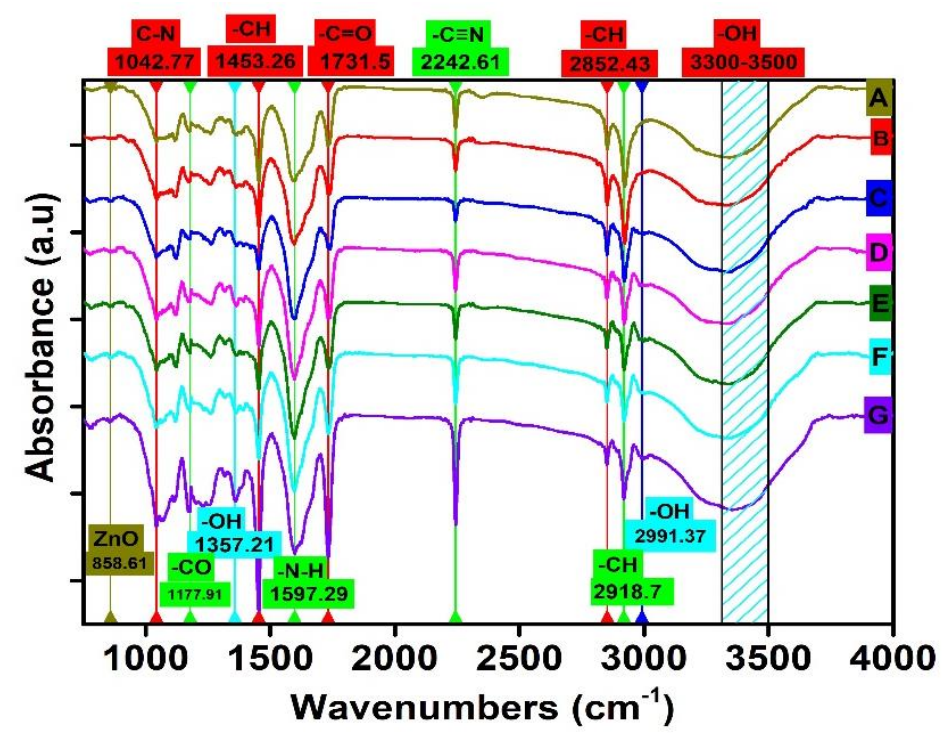

Figure 5. FTIR Analysis of VB-loaded ZnO/PAN electrospun nanofibers: (A) pristine PAN electrospun nanofibers; (B) ZnO/PAN electrospun nanofibers; (C) 0.5\% VB-loaded ZnO/PAN electrospun nanofibers; (D) 1.5\% VB-loaded ZnO/PAN electrospun nanofibers; (E) 2.5\% VB-loaded ZnO/PAN electrospun nanofibers; (F) 3.5\% VB-loaded ZnO/PAN electrospun nanofibers; (G) 5\% VB-loaded $\mathrm{ZnO} / \mathrm{PAN}$ electrospun nanofibers.

\subsection{Antibacterial Activity of PAN/ZnO, PAN/ZnO-Loaded Viroblock Electrospun Nanofibers}

Antibacterial activity of pristine PAN nanofibers, PAN/ZnO nanofibers, and PAN/ZnO nanofibers loaded with various concentrations of VB was observed by qualitative analysis followed by the AATCC-100 standard method. The antibacterial activity of all prepared electrospun nanofibers was tested against Gram-positive bacteria (Staphylococcus aureus) and Gram-negative bacteria (Pseudomonas aeruginosa). Figure 6a,b represents the antibacterial efficiency against Gram-positive bacteria and Gram-negative bacteria respectively. Pristine PAN electrospun nanofibers did not show any antibacterial activity. However, by the addition of the $\mathrm{ZnO}$ nanoparticles in the spinning solution, the PAN/ZnO electrospun nanofibers showed significant antibacterial efficiency against Gram-positive and Gram-negative bacteria. Figure 6 shows that PAN/ZnO electrospun nanofibers showed an antibacterial efficiency of $75.65 \%$ and $70.05 \%$ against Gram-positive Staphylococcus aureus and Gram-negative Pseudomonas aeruginosa, respectively, as metal oxide nanoparticles exhibited superior antibacterial properties, which suppressed the growth of both bacteria compared to the pure electrospun PAN nanofibers. Moreover, metal oxide nanoparticles provide reactive sites for the interaction of bacteria and nanofibers [47,48]. Additionally, metal oxides $(\mathrm{ZnO})$ act as bacteriostatic agents [49] with positive charges that attract the negatively charged bacteria with a strong electrostatic force of attraction. As a result of this electrostatic interaction, the molecular structure of the phospholipid is broken, and as a result the cell membrane is also damaged, causing the death of bacteria [50,51]. With the addition of $\mathrm{VB}$, the antibacterial efficiency of the electrospun nanofibers enhanced significantly against both Gram-positive bacteria as well as Gram-negative bacteria. VB contains silver particles that are potent antimicrobial as well as antiviral agents [34]. The addition of the VB in the spinning solution of the PAN/ZnO mixture resulted in the formation of $\mathrm{ZnO}-\mathrm{Ag}$ heterostructure nanoparticles on the surface of PAN electrospun nanofibers. These heterostructure $\mathrm{ZnO}-\mathrm{Ag}$ nanoparticles, when coming in contact with the bacteria, resulted in the disruption of the cell wall and cell membrane through a synergistic effect [52]. In addition, $\mathrm{ZnO}-\mathrm{Ag}$ heterostructures inhibit the replication of DNA in the microbial cell by releasing $\mathrm{Zn}^{+2}$ and $\mathrm{Ag}^{+}$ions [53]. Figure 7 shows that as the percentage of the VB increased, the antimicrobial efficiency further increased against both Gram-positive as well as Gram-negative bacteria, because by increasing the concentration of $\mathrm{VB}$, more 
and more $\mathrm{ZnO}-\mathrm{Ag}$ heterostructure came in contact with the bacterial cells, which led to significant enhancement of antibacterial efficiency. The maximum antibacterial efficiency shown by PAN/ZnO nanofibers loaded with $5 \%$ VB was $92.59 \%$ and $88.64 \%$ in the case of Staphylococcus aureus and Pseudomonas aeruginosa, respectively. Furthermore, Figure 6 shows that PAN/ZnO/VB hybrid composite electrospun nanofibers showed higher antimicrobial efficiency against Gram-positive than Gram-negative bacteria. This could be explained by one of possible three reasons. Firstly, the cell wall of Gram-negative bacteria is thicker than the cell wall of Gram-positive, and therefore $\mathrm{Zn}^{+2}$ or $\mathrm{Ag}^{+}$ions can easily penetrate the cell wall of Gram-positive bacteria rather than Gram-negative-bacteria [54,55]. Secondly, in comparison to Gram-positive bacteria, Gram-negative bacteria are more resistant to reactive oxygen species (ROS) due to the complex permeable barrier of the cell wall [56]. Thirdly, the cell membrane of Gram-positive bacteria has a less negative surface charge; hence, negative reactive oxygen species (ROS) can easily pass through the cell membrane [57].
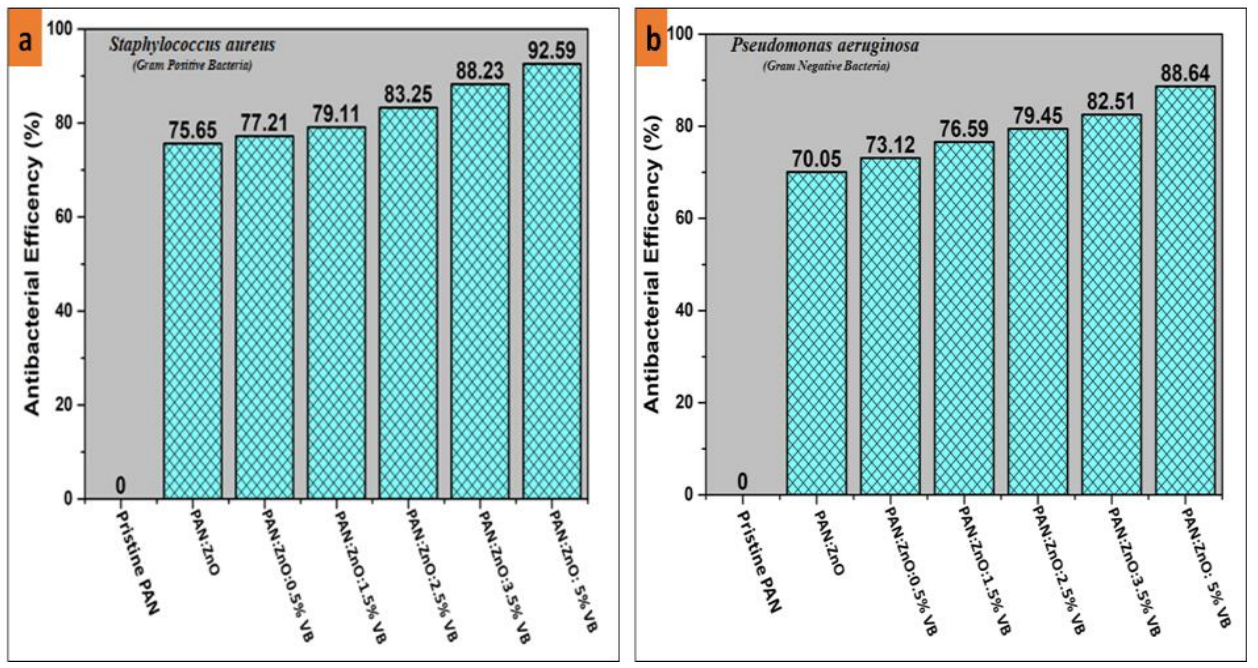

Figure 6. Antibacterial efficiency of pristine PAN electrospun nanofibers, $\mathrm{ZnO} / \mathrm{PAN}$ electrospun nanofibers, $0.5 \%$ VB-loaded $\mathrm{ZnO} / \mathrm{PAN}$ electrospun nanofibers, $1.5 \%$ VB-loaded $\mathrm{ZnO} / \mathrm{PAN}$ electrospun nanofibers, 2.5\% VB-loaded ZnO/PAN electrospun nanofibers, 3.5\% VB-loaded ZnO/PAN electrospun nanofibers, and 5\% VB-loaded ZnO/PAN electrospun nanofibers against (a)Staphylococcus aureus and (b) Pseudomonas aeruginosa.

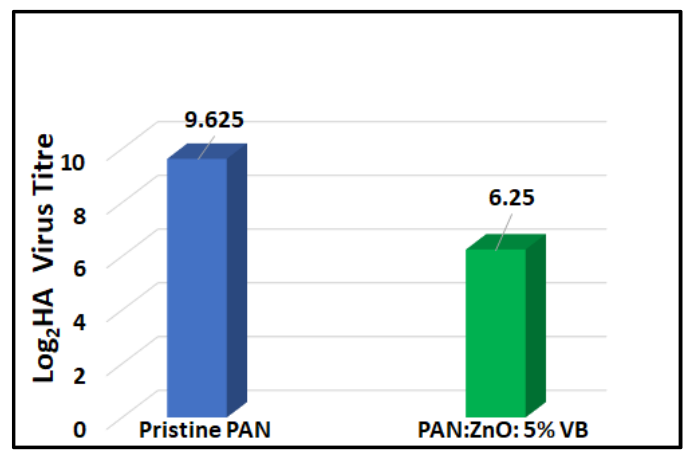

Figure 7. Antiviral activity of pristine PAN and 5\% VB-loaded PAN/ZnO electrospun nanofibers.

\subsection{Antiviral Activity of Pristine PAN Nanofibers and 5\% VB-Loaded PAN/ZnO Electrospun Nanofibers}

Prepared electrospun nanofibers were tested for the antiviral activity against the avian influenza virus. PAN/ZnO nanofibers loaded with the maximum concentration $(5 \%)$ of Viroblock were chosen for the antiviral activity, while pristine PAN nanofibers 
were used as a control sample. The plaque assay method was used to check the antiviral activity of prepared electrospun nanofibers. After three hours of contact with the virus, a significant decrease in the virus titers was observed, as shown in Figure 7, while in the case of pristine PAN nanofibers, there was negligible change in the virus titer. The average value of virus titer for the pristine electrospun nanofiber was 9.625, while in case of 5\%VB-loaded $\mathrm{PAN} / \mathrm{ZnO}$ electrospun nanofiber it was 6.25. From these results we can conclude that after three hours 5\%VB-loaded PAN/ZnO nanofibers showed significant (37.5\%) reduction as compared to the control sample, which showed a negligible reduction in the virus titer. The possible mechanism behind the high antiviral activity of VB-loaded nanofibers could be that VB contains silver ions and cosmetic-grade liposomes. Silver ions can kill viruses and bacteria due to their high surface energy and high surface area [34,35]. However, in the case of the influenza virus, the envelope of the lipid bilayer is present around the virus, which resists the penetration of the silver ions into the virus and thus protects the viral nucleocapsid from environmental stresses [58]. Due to this envelope, the efficiency of simple silver ions is not significant. To break the envelope of the virus, vesicle technology is used that contains cosmetic grade liposomes, which deplete the envelope membrane quickly so that the silver ions can attack the core of the virus and destroy the virus quickly. The possible mechanism of killing bacteria is shown in Figure 8.

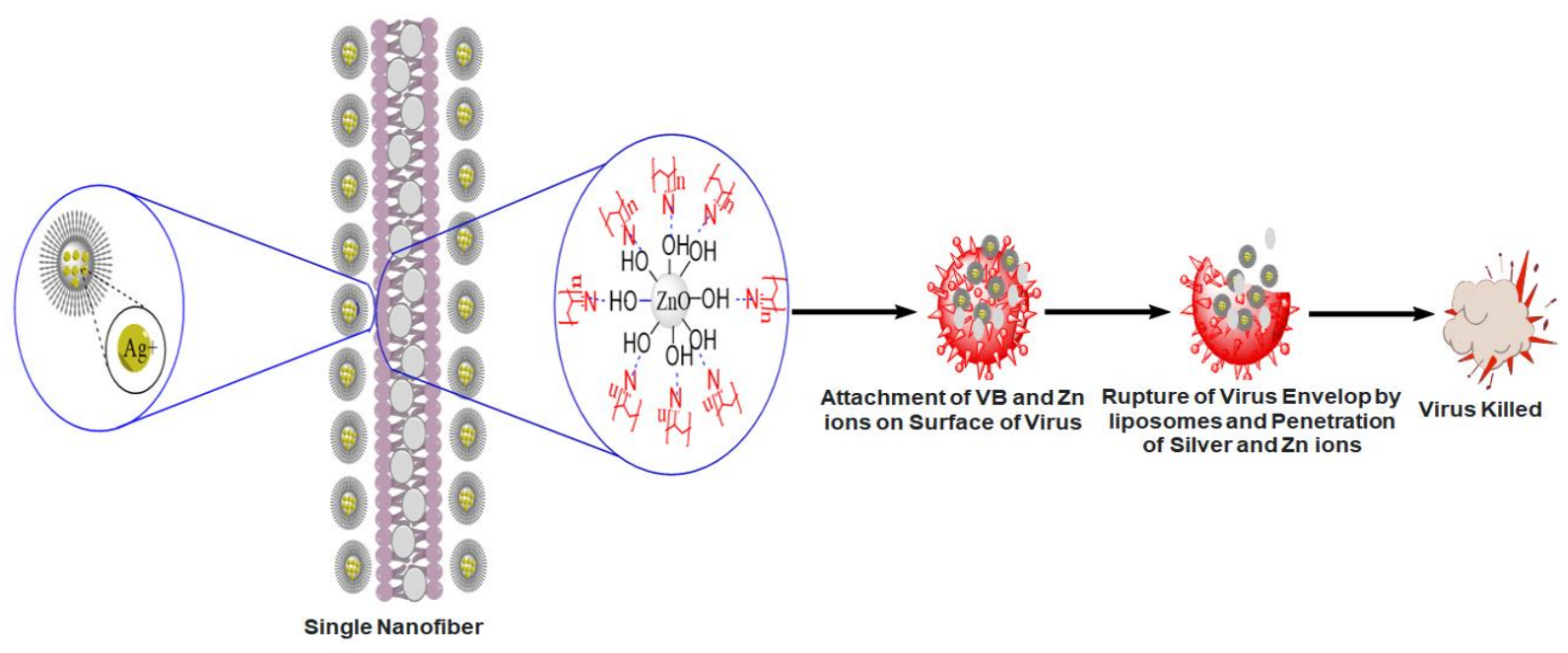

Figure 8. Schematic representation of antiviral activity of VB-loaded PAN/ZnO electrospun nanofibers.

\section{Conclusions}

This study is focused on the fabrication of antiviral nanofiber sheets by using the electrospinning technique. PAN/ZnO nanofibers were loaded with five different concentrations of Viroblock (acting as an antiviral agent). From the SEM analysis, it was confirmed that all the prepared electrospun nanofibers had smooth and bead-free surface morphologies. Uniform distribution of the $\mathrm{ZnO}$ and Viroblock in nanofibers was justified by using TEM analysis. FTIR analysis confirmed the physical interaction between PAN, $\mathrm{ZnO}$, and Viroblock. Qualitative antibacterial analysis proved the strong antibacterial activity against both Gram-positive bacteria (Staphylococcus aureus) and Gram-negative bacteria (Pseudomonas aeruginosa). Further, higher antibacterial activity was recorded for Gram-positive bacteria (Staphylococcus aureus) than Gram-negative bacteria (Pseudomonas aeruginosa), corresponding to the thicker and more complex permeability of the barrier cell wall of the latter. It was also found that as the concentration of the VB increased, the antibacterial activity also increased significantly. The 5\%VB-loaded PAN/ZnO electrospun nanofibers were used to check the antiviral activity against enveloped influenza virus. After three hours, a 37.5\% reduction in virus titer was found in the case of 5\%VB-loaded nanofibers as compared to pristine PAN nanofibers, which reveal the excellent antiviral activity of $5 \%$ VB-loaded nanofibers as compare to the pristine PAN nanofibers. From these 
results, it can be concluded that these VB-loaded PAN/ZnO electrospun nanofibers have great potential for the development of personal protective equipment such as facemasks and surgical gowns, which can play a key role in the protection of frontline health workers and the general public in the COVID-19 pandemic and onward.

Author Contributions: Conceptualization, A.S. and T.H.; methodology, M.W.; software, S.R.; validation, K.M.I., T.J. and A.K.; formal analysis, I.-S.K.; investigation, M.Q.K.; resources, M.Q.K.; data curation, T.H.; writing—original draft preparation, A.S.; writing-review and editing, S.u.K.; visualization, M.R.S.; supervision, M.Q.K.; project administration, A.S and M.Q.K.; funding acquisition, I.-S.K. All authors have read and agreed to the published version of the manuscript.

Funding: This research received no external funding.

Institutional Review Board Statement: Not applicable.

Informed Consent Statement: Not applicable.

Data Availability Statement: The data of this study are available from the corresponding author (M.Q.K.) upon reasonable request.

Conflicts of Interest: The authors declare no conflict of interest.

\section{References}

1. Asahi, K.; Undurraga, E.A.; Valdés, R.; Wagner, R. The effect of COVID-19 on the economy: Evidence from an early adopter of localized lockdowns. J. Glob. Health 2021, 11, 05002. [CrossRef]

2. Agarwal, P.; Singh, R. Modelling of transmission dynamics of Nipah virus (Niv): A fractional order Approach. Phys. A Stat. Mech. Appl. 2020, 547, 124243. [CrossRef]

3. Chauhan, S. Comprehensive review of coronavirus disease 2019 (COVID-19). Biomed. J. 2020, 43, 334-340. [CrossRef] [PubMed]

4. Elduma, A.H.; LaBeaud, A.D.; Plante, J.A.; Plante, K.S.; Ahmed, A. High Seroprevalence of Dengue Virus Infection in Sudan: Systematic Review and Meta-Analysis. Trop. Med. Infect. Dis. 2020, 5, 120. [CrossRef] [PubMed]

5. Borland, S.; Gracieux, P.; Jones, M.; Mallet, F.; Yugueros-Marcos, J. Influenza A Virus Infection in Cats and Dogs: A Literature Review in the Light of the "One Health" Concept. Front. Public Health 2020, 8, 83. [CrossRef]

6. Singhal, T. A Review of Coronavirus Disease-2019 (COVID-19). Indian J. Pediatr. 2020, 87, 281-286. [CrossRef]

7. Geller, C.; Varbanov, M.; Duval, R.E. Human Coronaviruses: Insights into Environmental Resistance and Its Influence on the Development of New Antiseptic Strategies. Viruses 2012, 4, 3044-3068. [CrossRef]

8. Pathogenesis of Viral Infections and Diseases. In Fenner's Veterinary Virology; Elsevier: Amsterdam, The Netherlands, 2017; pp. 47-78.

9. Howard, M.C. Understanding face mask use to prevent coronavirus and other illnesses: Development of a multidimensional face mask perceptions scale. Br. J. Health Psychol. 2020, 25, 912-924. [CrossRef]

10. Patel, A.; D'Alessandro, M.M.; Ireland, K.J.; Burel, W.G.; Wencil, E.B.; Rasmussen, S.A. Personal Protective Equipment Supply Chain: Lessons Learned from Recent Public Health Emergency Responses. Health Secur. 2017, 15, 244-252. [CrossRef]

11. Gralton, J.; McLaws, M.-L. Protecting healthcare workers from pandemic influenza: N95 or surgical masks? Crit. Care Med. 2010, 38, 657-667. [CrossRef]

12. Liao, L.; Xiao, W.; Zhao, M.; Yu, X.; Wang, H.; Wang, Q.; Chu, S.; Cui, Y. Can N95 Respirators Be Reused after Disinfection? How Many Times? ACS Nano 2020, 14, 6348-6356. [CrossRef] [PubMed]

13. Zangmeister, C.D.; Radney, J.G.; Vicenzi, E.; Weaver, J.L. Filtration Efficiencies of Nanoscale Aerosol by Cloth Mask Materials Used to Slow the Spread of SARS-CoV-2. ACS Nano 2020, 14, 9188-9200. [CrossRef] [PubMed]

14. Seino, S.; Imoto, Y.; Kosaka, T.; Nishida, T.; Nakagawa, T.; Yamamoto, T.A. Antiviral Activity of Silver Nanoparticles Immobilized onto Textile Fabrics Synthesized by Radiochemical Process. MRS Adv. 2016, 1, 705-710. [CrossRef]

15. Nozari, B.; Montazer, M.; Rad, M.M. In-Situ Synthesis of $\mathrm{SiO}_{2}$ Nanoparticles on Polyester Fabric as Benign Multi-Purpose Catalysts. Fibers Polym. 2018, 19, 2564-2573. [CrossRef]

16. Shaheen, T.I.; El-Naggar, M.E.; Abdelgawad, A.; Hebeish, A. Durable antibacterial and UV protections of in situ synthesized zinc oxide nanoparticles onto cotton fabrics. Int. J. Biol. Macromol. 2016, 83, 426-432. [CrossRef]

17. Shigita, S.; Tsurumi, H.; Naka, H. Anti-Viral Fiber, Process for Producing the Fiber, and Textile Product Comprising the Fiber. WO2005083171, 9 September 2007.

18. Imai, K.; Ogawa, H.; Bui, V.N.; Inoue, H.; Fukuda, J.; Ohba, M.; Yamamoto, Y.; Nakamura, K. Inactivation of high and low pathogenic avian influenza virus $\mathrm{H} 5$ subtypes by copper ions incorporated in zeolite-textile materials. Antivir. Res. 2012, 93, 225-233. [CrossRef]

19. Kumar, S.; Karmacharya, M.; Joshi, S.R.; Gulenko, O.; Park, J.; Kim, G.-H.; Cho, Y.-K. Photoactive Antiviral Face Mask with Self-Sterilization and Reusability. Nano Lett. 2021, 21, 337-343. [CrossRef] 
20. Zhang, Y.; Xu, Q.; Fu, F.; Liu, X. Durable antimicrobial cotton textiles modified with inorganic nanoparticles. Cellulose 2016, 23, 2791-2808. [CrossRef]

21. Yadav, A.; Prasad, V.; Kathe, A.A.; Raj, S.; Yadav, D.; Sundaramoorthy, C.; Vigneshwaran, N. Functional finishing in cotton fabrics using zinc oxide nanoparticles. Bull. Mater. Sci. 2006, 29, 641-645. [CrossRef]

22. Salam, A.; Khan, M.Q.; Hassan, T.; Hassan, N.; Nazir, A.; Hussain, T.; Azeem, M.; Kim, I.S. In-vitro assessment of appropriate hydrophilic scaffolds by co-electrospinning of poly(1,4 cyclohexane isosorbide terephthalate)/polyvinyl alcohol. Sci. Rep. 2020, 10, 19751. [CrossRef] [PubMed]

23. Monteiro, N.; Martins, A.; Pires, R.; Faria, S.; Fonseca, N.A.C.; Moreira, J.N.; Reis, R.L.; Neves, N.M. Immobilization of bioactive factor-loaded liposomes on the surface of electrospun nanofibers targeting tissue engineering. Biomater. Sci. 2014, 2, 1195-1209. [CrossRef]

24. Cui, W.Y.; Yoo, H.J.; Li, Y.G.; Baek, C.; Min, J. Electrospun Nanofibers Embedded with Copper Oxide Nanoparticles to Improve Antiviral Function. J. Nanosci. Nanotechnol. 2021, 21, 4174-4178. [CrossRef] [PubMed]

25. Rashid, M.M.O.; Islam, M.S.; Haque, M.A.; Rahman, M.A.; Hossain, M.T.; Hamid, M.A. Antibacterial activity of polyaniline coated silver nanoparticles synthesized from Piper betle leaves extract. Iran. J. Pharm. Res. 2016, 15, 591. [CrossRef]

26. Ji, S.-M.; Tiwari, A.P.; Oh, H.J.; Kim, H.-Y. ZnO/Ag nanoparticles incorporated multifunctional parallel side by side nanofibers for air filtration with enhanced removing organic contaminants and antibacterial properties. Colloids Surf. A Physicochem. Eng. Asp. 2021, 621, 126564. [CrossRef]

27. Kim, S.E.; Tiwari, A.P. Mussel-inspired polydopamine-enabled in situ-synthesized silver nanoparticle-anchored porous polyacrylonitrile nanofibers for wound-healing applications. Int. J. Polym. Mater. 2020, 1-10. [CrossRef]

28. Chowdhury, M.A.; Shuvho, B.A.; Shahid, A.; Haque, A.M.; Kashem, M.A.; Lam, S.S.; Ong, H.C.; Uddin, A.; Mofijur, M. Prospect of biobased antiviral face mask to limit the coronavirus outbreak. Environ. Res. 2021, 192, 110294. [CrossRef]

29. Karagoz, S.; Kiremitler, N.B.; Sarp, G.; Pekdemir, S.; Salem, S.; Goksu, A.G.; Onses, M.S.; Sozdutmaz, I.; Sahmetlioglu, E.; Ozkara, E.S.; et al. Antibacterial, Antiviral, and Self-Cleaning Mats with Sensing Capabilities Based on Electrospun Nanofibers Decorated with ZnO Nanorods and Ag Nanoparticles for Protective Clothing Applications. ACS Appl. Mater. Interfaces 2021, 13, 5678-5690. [CrossRef]

30. Wojnarowicz, J.; Chudoba, T.; Lojkowski, W. A Review of Microwave Synthesis of Zinc Oxide Nanomaterials: Reactants, Process Parameters and Morphologies. Nanomaterials 2020, 10, 1086. [CrossRef]

31. Ji, S.M.; Tiwari, A.P.; Kim, H.Y. Graphene Oxide Coated Zinc Oxide Core-Shell Nanofibers for Enhanced Photocatalytic Performance and Durability. Coatings 2020, 10, 1183. [CrossRef]

32. HeiQ Viroblock-HeiQ Materials AG. Available online: https://heiq.com/products/functional-textile-technologies/heiqviroblock/ (accessed on 16 August 2021).

33. Yin, I.X.; Zhang, J.; Zhao, I.S.; Mei, M.L.; Li, Q.; Chu, C.H. The Antibacterial Mechanism of Silver Nanoparticles and Its Application in Dentistry. Int. J. Nanomed. 2020, 15, 2555-2562. [CrossRef]

34. Galdiero, S.; Falanga, A.; Vitiello, M.; Cantisani, M.; Marra, V.; Galdiero, M. Silver Nanoparticles as Potential Antiviral Agents. Molecules 2011, 16, 8894-8918. [CrossRef]

35. Dung, T.T.N.; Nam, V.N.; Nhan, T.T.; Ngoc, T.T.B.; Minh, L.Q.; Nga, B.T.T.; Le, V.P.; Quang, D.V. Silver nanoparticles as potential antiviral agents against African swine fever virus. Mater. Res. Express 2019, 6, 1250g9. [CrossRef]

36. Xiao, Y.; Cao, Y.; Xin, B.; Liu, Y.; Chen, Z.; Lin, L.; Sun, Y. Fabrication and characterization of electrospun cellulose/polyacrylonitrile nanofibers with $\mathrm{Cu}(\mathrm{II})$ ions. Cellulose 2018, 25, 2955-2963. [CrossRef]

37. Blachowicz, T.; Ehrmann, A. Recent developments in electrospun ZnO nanofibers: A short review. J. Eng. Fibers Fabr. 2020, 15, 155892501989968. [CrossRef]

38. Iatsunskyi, I.; Vasylenko, A.; Viter, R.; Kempiński, M.; Nowaczyk, G.; Jurga, S.; Bechelany, M. Tailoring of the electronic properties of ZnO-polyacrylonitrile nanofibers: Experiment and theory. Appl. Surf. Sci. 2017, 411, 494-501. [CrossRef]

39. Ali, S.W.; Rajendran, S.; Joshi, M. Synthesis and characterization of chitosan and silver loaded chitosan nanoparticles for bioactive polyester. Carbohydr. Polym. 2011, 83, 438-446. [CrossRef]

40. Cheah, W.Y.; Show, P.-L.; Ng, I.-S.; Lin, G.-Y.; Chiu, C.-Y.; Chang, Y.-K. Antibacterial activity of quaternized chitosan modified nanofiber membrane. Int. J. Biol. Macromol. 2019, 126, 569-577. [CrossRef]

41. Nazaktabar, A.; Lashkenari, M.S.; Araghi, A.; Ghorbani, M.; Golshahi, H. In vivo evaluation of toxicity and antiviral activity of polyrhodanine nanoparticles by using the chicken embryo model. Int. J. Biol. Macromol. 2017, 103, 379-384. [CrossRef]

42. Fang, S.; Wang, W.; Yu, X.; Xu, H.; Zhong, Y.; Sui, X.; Zhang, L.; Mao, Z. Preparation of ZnO:(Al, La)/polyacrylonitrile (PAN) nonwovens with low infrared emissivity via electrospinning. Mater. Lett. 2015, 143, 120-123. [CrossRef]

43. Yu, H.; Jiao, Z.; Hu, H.; Lu, G.; Ye, J.; Bi, Y. Fabrication of $\mathrm{Ag}_{3} \mathrm{PO}_{4}-\mathrm{PAN}$ composite nanofibers for photocatalytic applications. CrystEngComm 2013, 15, 4802-4805. [CrossRef]

44. Dalton, S.; Heatley, F.; Budd, P.M. Thermal stabilization of polyacrylonitrile fibres. Polymer 1999, 40, 5531-5543. [CrossRef]

45. Shah, A.P.; Jain, S.; Mokale, V.J.; Shimpi, N.G. High performance visible light photocatalysis of electrospun PAN/ZnO hybrid nanofibers. J. Ind. Eng. Chem. 2019, 77, 154-163. [CrossRef]

46. Karim, S.A.; Mohamed, A.; Abdel-Mottaleb, M.; Osman, T.; Khattab, A. Visible light photocatalytic activity of PAN-CNTs/ZnONH2 electrospun nanofibers. J. Alloy. Compd. 2019, 772, 650-655. [CrossRef] 
47. Chauhan, D.; Afreen, S.; Mishra, S.; Sankararamakrishnan, N. Synthesis, characterization and application of zinc augmented aminated PAN nanofibers towards decontamination of chemical and biological contaminants. J. Ind. Eng. Chem. 2017, 55, 50-64. [CrossRef]

48. Wasim, M.; Shi, F.; Liu, J.; Farooq, A.; Khan, S.U.; Salam, A.; Hassan, T.; Zhao, X. An overview of Zn/ZnO modified cellulosic nanocomposites and their potential applications. J. Polym. Res. 2021, 28, 338. [CrossRef]

49. Unuabonah, E.I.; Kolawole, M.O.; Agunbiade, F.O.; Omorogie, M.O.; Koko, D.T.; Ugwuja, C.G.; Ugege, L.E.; Oyejide, N.E.; Günter, C.; Taubert, A. Novel metal-doped bacteriostatic hybrid clay composites for point-of-use disinfection of water. J. Environ. Chem. Eng. 2017, 5, 2128-2141. [CrossRef]

50. Motshekga, S.C.; Ray, S.S.; Maity, A. Synthesis and characterization of alginate beads encapsulated zinc oxide nanoparticles for bacteria disinfection in water. J. Colloid Interface Sci. 2018, 512, 686-692. [CrossRef]

51. Rajavel, K.; Gomathi, R.; Manian, S.; Kumar, R.T.R. In Vitro Bacterial Cytotoxicity of CNTs: Reactive Oxygen Species Mediate Cell Damage Edges over Direct Physical Puncturing. Langmuir 2013, 30, 592-601. [CrossRef]

52. Wang, S.; Wu, J.; Yang, H.; Liu, X.; Huang, Q.; Lu, Z. Antibacterial activity and mechanism of Ag/ZnO nanocomposite against anaerobic oral pathogen Streptococcus mutans. J. Mater. Sci. Mater. Med. 2017, 28, 23. [CrossRef]

53. Patel, S.; Konar, M.; Sahoo, H.; Hota, G. Surface functionalization of electrospun PAN nanofibers with ZnO-Ag heterostructure nanoparticles: Synthesis and antibacterial study. Nanotechnology 2019, 30, 205704. [CrossRef] [PubMed]

54. Sohrabnezhad, S.; Moghaddam, M.J.M.; Salavatiyan, T. Synthesis and characterization of CuO-montmorillonite nanocomposite by thermal decomposition method and antibacterial activity of nanocomposite. Spectrochim. Acta Part A Mol. Biomol. Spectrosc. 2014, 125, 73-78. [CrossRef]

55. Motshekga, S.C.; Ray, S.S. Highly efficient inactivation of bacteria found in drinking water using chitosan-bentonite composites: Modelling and breakthrough curve analysis. Water Res. 2017, 111, 213-223. [CrossRef]

56. Munnawar, I.; Iqbal, S.S.; Anwar, M.N.; Batool, M.; Tariq, S.; Faitma, N.; Khan, A.L.; Khan, A.U.; Nazar, U.; Jamil, T.; et al. Synergistic effect of Chitosan-Zinc Oxide Hybrid Nanoparticles on antibiofouling and water disinfection of mixed matrix polyethersulfone nanocomposite membranes. Carbohydr. Polym. 2017, 175, 661-670. [CrossRef]

57. Gordon, T.; Perlstein, B.; Houbara, O.; Felner, I.; Banin, E.; Margel, S. Synthesis and characterization of zinc/iron oxide composite nanoparticles and their antibacterial properties. Colloids Surfaces A Physicochem. Eng. Asp. 2011, 374, 1-8. [CrossRef]

58. Firquet, S.; Beaujard, S.; Lobert, P.-E.; Sane, F.; Caloone, D.; Izard, D.; Hober, D. Survival of Enveloped and Non-Enveloped Viruses on Inanimate Surfaces. Microbes Environ. 2015, 30, 140-144. [CrossRef] 